\title{
Selection of Environmentally Conscious Manufacturing's Program Using Multi-Criteria Decision Making: A Case Study in Electronic Company
}

\author{
I Nyoman Sutapa ${ }^{\dagger}$ \\ Industrial Engineering Department, Petra Christian University, Surabaya, Indonesia \\ E-mail: mantapa@petra.ac.id \\ Togar W. S. Panjaitan \\ Industrial Engineering Department, Petra Christian University, Surabaya, Indonesia \\ E-mail: togar@petra.ac.id
}

Received, January 18, 2011; Revised, April 20, 2011; Accepted, April 26, 2011

\begin{abstract}
Nowadays, green purchasing, stop global warming, love the mother earth, and others that related to environment become hot issues. Manufactures industries tend to more active and responsive to those issues by adopting green strategies or program like Environmentally Conscious Manufacturing (ECM). In this article, an electronic company had applied 12 ECM Program and tries to choose one of those programs using 6 criteria, such as total cost involved, quality, recyclable material, process waste reduction, packaging waste reduction, and regulation compliance. By using multi-criteria decision making model, i.e. Analytical Hierarchy Process (AHP), Technique for Order Preference by Similarity to Ideal Solution (TOPSIS), and Modified TOPSIS methods, the ECM Program 9 (Open pit) is the best option.
\end{abstract}

Keywords: Environmentally Conscious Manufacturing (ECM), Electronic Company, AHP, Technique for Order Preference by Similarity to Ideal Solution (TOPSIS), Modified TOPSIS

\section{INTRODUCTION}

Climate change is a problem with unique chaaterisics. It is global, long-term (up to several centuries), and involves complex interactions between climatic, environmental, economic, political, institutional, social and technological processes (IPCC, 2001).

It is now widely accepted that failing to act to mitigate the impacts of climate change will cost more in the long-term. An integrated assessment of technologies must if possible take into consideration the changes in production patterns that will result from innovation and climate policy.

Industries in all around the world must put strong consideration to use appropriate technologies and sysematic approaches that can reduce wastes. Environmental Conscious Manufacturing (ECM) is one of the tools that can be used for integrated assessment of technologies to improve capability to reduce waste.

An electronics company has implemented the 12 ECM Programs. Currently, the company wants to choose one among the twelve program uses six criteria, namely cost, quality, material can be recycled, waste reduction processes, reducing waste packaging, and regulatory compliance.

In this case study, none of the ECM program that all criteria have the highest value compared with other ECM programs. If only using cost criteria, ECM program 1 has the highest value is an ECM program. While in the process of waste reduction criteria, ECM program 8 has the highest value.

By those problems, needs the existence of a study that can evaluate and analyze the best alternative ECM program based on all criteria from the results of all model calculations, and criteria that have the largest weighting among the six criteria that used to select the 12 alternative ECM programs.

\section{BASIC THEORY}

In this chapter, we will discuss about the image of Environmentally Conscious Manufacturing (ECM) and counting steps with Analytical Hierarchy Process (AHP),

$\dagger$ : Corresponding Author 
Technique for Order Preference by Similarity to Ideal Solution (TOPSIS), and modified TOPSIS as tools to choose which option is more suitable to implement.

\subsection{Environmentally Conscious Manufacturing}

ECM is a systematic approach to products and process designs, in which environmental criteria are treated as a primary goal or an opportunity and not as a limitation (Billatos, 2004).

There are four main objectives the implementation of ECM, namely waste reduction, material management, pollution prevention, and product enhancement (Gupta, 2008).

Application of ECM in the industrialized world is expected to reduce industrial wastes. Industries have to do preventing environmental pollutions by implementing cleaner technologies, installing the pollution prevention equipment, do the recycling process, and conduct processing of industrial waste materials to minimize pollution until achieve the limit.

Application of ECM in the industrialized world is expected to reduce the amount of hazardous materials which is the source of environmental pollution. Management of materials by the industrialized world can follow the procedure Environmental Management System (EMS) that exist in ISO 14001, such as reduced use of materials containing lead and mercury com-pounds.

Benefits of pollution prevention are a healthy environment and free from pollution, reduce or eliminate the potential to be harmful to the environment, reduce the risk of worker safety and health, a stable pollution compliance costs, and enhance the company image in the eyes of customers and society.

Indirectly, the aim of implementation the ECM is for products enchancement. In this case, product enchancement is a product that associate with the re-duction in the number of sections or parts, prioritization features that easily disassembled, and the use of components that are modular.

According to Kutz (2007) and Gupta (2008) there are six main criteria that can be used to assess the performance of ECM programs implementation, i.e. total cost, product quality, energy consumption, consumption of raw materials, waste treatment, and government regulations.

Total costs are the costs incurred when implement-ing ECM programs. Major criteria and the total cost of which varies depending on the cost factor is used. In general, the total cost can be viewed from the large investment cost to implement the ECM program that usually includes the purchase of equipments, purchase of materials, consulting, and business license fees. Besides that, the investment costs which included in the total cost are the cost of care, labor costs, documentation costs, and inspection fees.

ECM is expected to improve product quality directly, and product quality is also associated with the use of materials. The better the quality of materials used, it can also directly improve the quality of products, and the ECM program criteria that related to product quality can be evaluated from the numbers of defect ratio in the production process.

The energy consumption associated with the production process. More effective production process will make more effective of using energy, which can improve environmental sustainability.

Consumption of effective and not harmful raw materials are very influential on product qualities and waste treatment processes.

Sewage treatment is closely related to the materials used and toxic emissions. The higher the content of harmful substances in the product material, more difficult to process and the higher emissions of noxious gases contained.

In this case, compliance with government regulations entirely will depend on individual company policy. The Indonesian government regulations relating to the environment set out in Government Regulation No.74 year 2001 on Management of Hazardous and Toxic Materials. While international regulations adopted by the world's many related industries with ISO 14001.

\subsection{Analytical Hierarchy Process (AHP)}

AHP is part of a multi-criteria decision making techniques which can be used to make decisions involving more than one criteria (Saaty, 2001).

The first step in AHP model is determine the objectives, decision alternatives, and criteria, and then making pair-wise comparison matrix to determine the relative importance among the alternatives and the existing criteria to each others. In this approach, decision makers must be able to give their opinion about the value of such comparisons. The next steps are calculation of the normalized relative weight of each criteria by calculating the geometric mean. Finally, the normalized weights are calculated by comparing pair-wise values obtained with a total value of the pair-wise (Saaty, 2001).

\subsection{Technique for Order Preference by Similarity to Ideal Solution (TOPSIS)}

The TOPSIS method used to define an ideal solution from the negative ideal solution. In this case, the ideal solution is a solution that maximizes the attributes useful (beneficial attribute) and to minimize nonbeneficial attributes (non-beneficial attribute). There-fore, the negative ideal solution is a solution that maximizes the attributes of non benefits and minimize the beneficial attributes.

As for the steps in TOPSIS (Willis, 2000) are: determination of objectives and identifies the evaluation criteria in questions. Making the matrix based on all available information on these criteria. Each row of the matrix is destined to one alternative and each column to 
one critera. Therefore, the element $M_{i j}$ of decision tables provide the value of alternative $i$ for criteria $j$. Calculation of normalized decision matrix $R$ using the formula:

$$
R_{i j}=\frac{m_{i j}}{\left[\sum_{j=1}^{M} m^{2} i j\right]^{1 / 2}}
$$

The relative importance of different criteria is accordance with the target. $W_{J}$ series of weights (for $j$ $=1,2, \cdots, M$ ) such $\sum_{w j}=1$ can be decided. The elements of the normalization of the weight matrix $V$ is expressed as follows:

$$
V_{i j}=w_{j} \times R_{i j}
$$

Calculation the positive ideal solution $\left(V^{+}\right)$and negative ideal solution $(V)$. Positive ideal solution and negative ideal solution can be expressed as follows:

$$
\begin{aligned}
V^{+} & =\left\{\left(\sum_{i}^{\max } V_{i j} / j \in J\right),\left(\sum_{i}^{\min } V_{i j} / j \in J\right) / i=1,2, \cdots \cdots, N\right\} \\
& =\left\{V_{1}^{+}, V_{2}^{+}, V_{3}^{+}, \cdots \cdots, V_{M}^{+}\right\} \\
V^{-} & =\left\{\left(\sum_{i}^{\min } V_{i j} / j \in J^{\prime}\right),\left(\sum_{i}^{\max } V_{i j} / j \in J^{\prime}\right) / i=1,2, \cdots \cdots, N\right\} \\
& =\left\{V_{1}^{-}, V_{2}^{-}, V_{3}^{-}, \cdots \cdots, V_{M}^{-}\right\}
\end{aligned}
$$

Note: $J=(j=1,2,3, \cdots, M) / j=$ beneficial attributes

$$
\begin{gathered}
J^{\prime}=\underset{\text { attributes }}{(j=1,2,3, \cdots, M)} / j=\text { non beneficial } \\
\text { attion }
\end{gathered}
$$

Moreover, Euclidean distance can be calculated by:

$$
\begin{aligned}
& S_{i}^{+}=\left[\sum_{J=1}^{M}\left(V_{i j}-V_{j}^{+}\right)^{2}\right]^{0,5}, i=1,2,3, \cdots \cdots, \quad N \\
& S_{i}^{-}=\left[\sum_{J=1}^{M}\left(V_{i j}-V_{j}^{-}\right)^{2}\right]^{0,5}, i=1,2,3, \cdots \cdots, \quad N
\end{aligned}
$$

The relative closeness of a particular alternative to the ideal solution can be calculated using the formula:

$$
P_{i}=\frac{S_{i}^{-}}{S_{i}^{+}+S_{i}^{-}}
$$

Finally, ordering a set of alternatives based on the value of $P_{i}$ is the largest to smallest. Ordering-mod $P_{i}$ value indicates possible solutions to the most preferred and least preferred.
2.4 The Technique for Order Preference by Similarity to Ideal Solution (TOPSIS) Modification

In this method, the calculation is not different with TOPSIS method but only in the Euclidean distance calculation step, namely (Willis, 2000):

Calculating the value of a positive ideal solution $\left(\mathrm{R}^{+}\right)$and negative ideal solution $\left(\mathrm{R}^{-}\right)$with the formula:

$$
\begin{aligned}
R^{+} & =\left\{\left(\sum_{i}^{\max } R_{i j} / j \in J\right),\left(\sum_{i}^{\min } R_{i j} / j \in J^{\prime}\right) / i=1,2, \cdots \cdots, N\right\} \\
& =\left\{R_{1}^{+}, R_{2}^{+}, R_{3}^{+}, \cdots \cdots, R_{M}^{+}\right\} \\
R^{-} & =\left\{\left(\sum_{i}^{\min } R_{i j} / j \in J\right),\left(\sum_{i}^{\max } R_{i j} / j \in J^{\prime}\right) / i=1,2, \cdots . ., N\right\} \\
& =\left\{R_{1}^{-}, R_{2}^{-}, R_{3}^{-}, \cdots \cdots, R_{M}^{-}\right\} \\
: J & =(j=1,2,3, \ldots, M) / j=\text { beneficial attributes } \\
J^{\prime} & =(j=1,2,3, \ldots, M) / j=\text { non beneficial attributes }
\end{aligned}
$$

Euclidean distance weighting calculations using:

$$
\begin{aligned}
& D_{i}^{+}=\left[\sum_{J=1}^{M} W_{j}\left(R_{i j}-R_{j}^{+}\right)^{2}\right]^{0,5}, i=1,2,3, \cdots, N \\
& D_{i}^{-}=\left[\sum_{J=1}^{M} W_{j}\left(R_{i j}-R_{j}^{-}\right)^{2}\right]^{0,5}, \quad i=1,2,3, \cdots, N
\end{aligned}
$$

Calculating the relative closeness of a particular alternative to the ideal solution can be calculated using the formula:

$$
P_{i-\bmod }=\frac{D_{i}^{-}}{D_{i}^{+}+D_{i}^{-}}
$$

Finally, ordering a set of alternatives based on the value of Pi-mod is from the largest to smallest. Orderingmod $P i$ value indicates possible solutions to the most preferred and least preferred.

\section{RESEARCH METHOD}

The data collected from interviews with the company (Research and Development Manager). The interview was conducted on the detail of each alternative ECM programs and their advantages and drawbacks, the influential criteria in choosing alternative ECM program, a relationship or interaction among the criteria, the total cost needed to realize the ECM program, product quality, energy consumption, consumption of raw materials, number of wastes or toxic emissions, 
waste treatment, waste packaging, recycling, government regulations, the flow of production processes, technologies used, and consumer demands. All the information collected to be input to conduct the research. Research carried out according to the conditions and requirements so that companies can be applied and utilized with maximum.

\section{DATA ANALYSIS}

12 ECM Alternative Programs have been implemented by company, showed on Table 2 (Theresia, 2009).

Table 2. ECM Alternatives Program.

\begin{tabular}{|c|c|c|c|c|}
\hline \multirow{3}{*}{$\begin{array}{c}\text { ECM } \\
\text { Program }\end{array}$} & \multicolumn{4}{|c|}{ Environmental Factors } \\
\hline & \multirow{2}{*}{$\begin{array}{l}\text { Number } \\
\text { of Part } \\
\text { (unit) }\end{array}$} & \multicolumn{2}{|c|}{ Type of material } & \multirow{2}{*}{$\begin{array}{c}\text { Wastewater } \\
\text { treatment tech- } \\
\text { niques }\end{array}$} \\
\hline & & $\begin{array}{c}\text { Polycar- } \\
\text { bonat } \\
\text { type }\end{array}$ & $\begin{array}{c}\text { Magnetic } \\
\text { tapes } \\
\text { type } \\
\end{array}$ & \\
\hline 1 & 17 & 8905 & 508 & Rotary kiln \\
\hline 2 & 21 & 8907 & 508 & Multiple hearth \\
\hline 3 & 18 & 8905 & 506 & Fluidized bed \\
\hline 4 & 21 & 8906 & 507 & Multiple hearth \\
\hline 5 & 19 & 8907 & 507 & Multiple chamber \\
\hline 6 & 19 & 8905 & 507 & Rotary kiln \\
\hline 7 & 21 & 8905 & 508 & Single chamber \\
\hline 8 & 17 & 8905 & 507 & Single chamber \\
\hline 9 & 18 & 8907 & 507 & Open pit \\
\hline 10 & 21 & 8905 & 506 & Open pit \\
\hline 11 & 18 & 8906 & 508 & Fluidized bed \\
\hline 12 & 17 & 8907 & 506 & Fluidized bed \\
\hline
\end{tabular}

Table 3. 12 ECM Implementation Program and Results of Six criteria.

\begin{tabular}{|c|c|c|c|}
\hline $\begin{array}{c}\text { ECM } \\
\text { Program }\end{array}$ & $\begin{array}{c}\text { ECMP-AHP } \\
\text { (AHP) }\end{array}$ & $\begin{array}{c}P i \\
\text { (TOPSIS) }\end{array}$ & $\begin{array}{c}P_{\text {i-mod }} \\
\text { (Modified } \\
\text { TOPSIS) }\end{array}$ \\
\hline \hline 1 & 0.695 & 0.510 & 0.424 \\
\hline 2 & 0.513 & 0.309 & 0.266 \\
\hline 3 & 0.802 & 0.653 & 0.623 \\
\hline 4 & 0.614 & 0.476 & 0.452 \\
\hline 5 & 0.578 & 0.363 & 0.386 \\
\hline 6 & 0.558 & 0.442 & 0.499 \\
\hline 7 & 0.775 & 0.638 & 0.630 \\
\hline 8 & 0.732 & 0.548 & 0.520 \\
\hline 9 & 0.762 & 0.682 & 0.671 \\
\hline 10 & 0.764 & 0.678 & 0.624 \\
\hline 11 & 0.558 & 0.376 & 0.360 \\
\hline 12 & 0.522 & 0.332 & 0.327 \\
\hline
\end{tabular}

In Table 3, we can see the implementation of 12 ECM Program along with the results of the six criteria (total cost involved, quality, recyclable materials, process waste reduction, packaging waste reduction, and regulation compliance).

Criteria C (cost) and Q (quality) in Table 3 are included in non-beneficial attributes, which lower the value the more desirable. Meanwhile, the remaining criteria such as R (recyclable materials), PWR (process waste reduction), PGR (packaging waste reduction), and RC (regulatory compliance) are the beneficial attribute, which is the higher the value the more desirable. At Table 3 can be seen that no single ECM program that all criteria have the highest value compared with other ECM programs. Therefore, to determine the best alternative ECM program based on all criteria were counted with the method of AHP, TOPSIS, and modified TOPSIS

Table 4. Pairwise Comparisons between Criteria.

\begin{tabular}{|c|c|c|c|c|c|c|}
\hline & $\mathrm{C}$ & $\mathrm{Q}$ & $\mathrm{R}$ & PWR & PGR & RC \\
\hline \hline $\mathrm{C}$ & 1 & 3 & 2 & 1 & 2 & 3 \\
\hline $\mathrm{Q}$ & 0.33 & 1 & 0.33 & 0.25 & 0.33 & 1 \\
\hline $\mathrm{R}$ & 0.5 & 3 & 1 & 0,5 & 0.5 & 2 \\
\hline PWR & 1 & 4 & 2 & 1 & 2 & 4 \\
\hline PGR & 0.5 & 3 & 2 & 0.5 & 1 & 2 \\
\hline RC & 0.33 & 1 & 0.5 & 0.25 & 0.5 & 1 \\
\hline
\end{tabular}

Tabel 5. The Weight of ECM Program based on AHP, TOPSIS, and Modified TOPSIS.

\begin{tabular}{|c|c|c|c|c|c|c|}
\hline $\begin{array}{c}\text { ECM } \\
\text { Program }\end{array}$ & $\begin{array}{c}\mathrm{C} \\
(\mathbf{\$})\end{array}$ & $\begin{array}{c}\mathrm{Q} \\
(\%)\end{array}$ & $\begin{array}{c}\mathrm{R} \\
(\%)\end{array}$ & $\begin{array}{c}\text { PWR } \\
(\%)\end{array}$ & $\begin{array}{c}\text { PGR } \\
(\%)\end{array}$ & $\begin{array}{c}\text { RC } \\
(\%)\end{array}$ \\
\hline \hline 1 & $28,546.45$ & 2.02 & 5 & 0.54 & 0.33 & 12 \\
\hline 2 & $45,956.87$ & 2.26 & 5 & 0.38 & 0.30 & 15 \\
\hline 3 & $36,475.94$ & 2.73 & 11 & 0,53 & 0.71 & 47 \\
\hline 4 & $40,706.87$ & 2.94 & 15 & 0,32 & 0.64 & 8 \\
\hline 5 & $63,546.45$ & 2.68 & 8 & 0.41 & 0.53 & 35 \\
\hline 6 & $46,346.45$ & 2.88 & 23 & 0.25 & 0.33 & 32 \\
\hline 7 & $50,956.87$ & 1.47 & 19 & 0.53 & 0.71 & 24 \\
\hline 8 & $51,225.94$ & 2,64 & 6 & 0.58 & 0.70 & 40 \\
\hline 9 & $48,075.94$ & 1.98 & 28 & 0.54 & 0.51 & 21 \\
\hline 10 & $32,056.87$ & 2.50 & 23 & 0.53 & 0.37 & 19 \\
\hline 11 & $38,625.94$ & 1,92 & 3 & 0.40 & 0.21 & 34 \\
\hline 12 & 57.546 .45 & 2,39 & 5 & 0.29 & 0.72 & 7 \\
\hline
\end{tabular}

Based on the results of the calculation of weight with all three methods, AHP, TOPSIS, and modified TOPSIS, the waste reduction process is the highest weight, i.e. 0.288 . While the sequence of the remaining five criteria from the greatest to the smallest are total cost involved (0.261), packaging waste reduction $(0.173)$, recyclable material $(0.137)$, regulatory com- 
pliance (0.075) and quality (0.066).

If policy makers find it difficult to decide where is the best ECM program, it can be done to final selection. The final selection is done by combining the results from methods that produce consistent ratings.

In Table 6. column $\mathrm{M}$ is the average yield ranking of the three existing methods, ie AHP, TOPSIS, and modified TOPSIS. The average results of those methods are considered to provide an intuitive understanding. However, since rank $M$ represents the average results from different methods which lead to the similarity to the ECM program selection, we need a processing technique that can provide an alternative picture of the sequence significantly. One technique is to conduct an alternative sequence of adjustment results in column $\mathrm{M}$. Results third adjustment method is shown in column $\mathrm{M}^{*}$.

Table 6. Comparison of Weight of ECM Program based on AHP, TOPSIS, and Modified TOPSIS.

\begin{tabular}{|c|c|c|c|c|c|}
\hline $\begin{array}{c}\text { ECM } \\
\text { Program }\end{array}$ & AHP & TOPSIS & $\begin{array}{c}\text { Modified } \\
\text { TOPSIS }\end{array}$ & $M$ & $M^{*}$ \\
\hline \hline 1 & 6 & 6 & 8 & 6.667 & 6 \\
\hline 2 & 12 & 12 & 12 & 12 & 12 \\
\hline 3 & 1 & 3 & 4 & 2.667 & 4 \\
\hline 4 & 7 & 7 & 7 & 7 & 7 \\
\hline 5 & 8 & 10 & 9 & 9 & 9 \\
\hline 6 & 9 & 8 & 6 & 7.667 & 8 \\
\hline 7 & 2 & 4 & 2 & 2.667 & 2 \\
\hline 8 & 5 & 5 & 5 & 5 & 5 \\
\hline 9 & 4 & 1 & 1 & 2 & 1 \\
\hline 10 & 3 & 2 & 3 & 2.667 & 3 \\
\hline 11 & 10 & 9 & 10 & 9.667 & 10 \\
\hline 12 & 11 & 11 & 11 & 11 & 11 \\
\hline
\end{tabular}

In column M, ECM Program 3, 7, and 10 are both located at the 2.667 level. After the adjustment, then the ECM Program 3, 7, and 10 respectively ranked fourth, second, and third. However, based on math, actually ECM Program 3, 7, and 10 have the same rank (ranks in numbers). Meanwhile, on 11 and 12 rank the three methods provide an absolute ranking of the ECM Program 12 and ECM Program 2.

By using the result of the three methods above, the sequence of alternative ECM program is ECM program 9, ECM Program 7, Program ECM 10, ECM Program 3, ECM program 8, ECM Program 1, Program 4 ECM, ECM Programme 6, ECM Program 5, Program ECM 11, ECM Program 12, and ECM Programme 2. So, we can conclude that the ECM program 9 is the option most suitable to be applied further in the company.

\section{CONCLUCION}

There are six criteria that used to select the 12 al- ternative ECM program, and found that the weight of the process waste reduction criteria is the highest weight, i.e. 0.288 . While the sequence of the remaining five criteria weights from the greatest to the smallest are total cost involved (0.261), packaging waste reduction (0.173), recyclable material $(0.137)$, regulatory compliance (0.075) and quality (0.066).

Based on the combination of three methods, namely AHP, TOPSIS, and modified TOPSIS, we can conclude that ECM program 9 more suitable than others.

This case study has limitation because the criteria really depend on the characteristic of the products. Further research should be done to find sustainable indicators to quantify the sustainability of various measures, processes, products and various types of materials. It will support to establish a specific list of indicators that can be applied for measurement of sustainability in the various stages of the life cycle of a specific manufactures.

\section{REFERENCES}

Billatos, S. (2004), Green Technology and Design for the Environment, Oregon: Taylor and Francis, Ltd.

Gupta, S. (2008), Environment Conscious Manufacturing, Oregon: Taylor and Francis, Ltd.

IPCC, Climate change (2001), synthesis report, A Contribution of Working Groups I, II, and III to the Third Assessment Report of the Intergovernmental Panel on Climate Change, Cambridge, UK: ambridge University.

Kutz, M. (2007), Environmentally Conscious Manufacturing, New Jersey: John Wiley and Sons, Inc.

Perry, C. (2003), Perry's Chemical Engineers' handbook. Singapura: McGraw Hill.

Rao, R. V. (2008), Evaluation of environmentally conscious manufacturing programs using multiple attribute decision-making methods, Proc. IMechE 222 Part B: J. Engineering Manufacture.

Saaty, T. (2001), How to Make and Justify Decision: The Analytic Hierarchy Process (AHP), Pittsburgh: RWS Publication.

Saaty, T. and Vargas, L. G. (2001), Models, Methods, Concepts and Applications of the Analytical Hierarchy Process, Springer Publishing.

Suryadi, K. (2002), Sistem Pendukung Keputusan, Bandung: PT Remaja Rosdakarya.

Theresia, A. M. (2009), Penentuan Program ECM Terbaik dengan Pendekatan AHP, TOPSIS, dan Mofifikasi Topsis di sebuah Perusahaan Elektronik, Final Project, Industrial Engineering Dept., Petra Christian University, Surabaya.

Willis, R. (2000), Inter Company Comparison using TOPSIS with Objective Weight, Berlin: Spinger. 